\title{
Formal-Dogmatic Approach in Legal Science in Present Conditions
}

\author{
Alexander V. Petrov and Alexey V. Zyryanov* \\ South Ural State University \\ 76 Lenin, Chelyabinsk, 454080, Russia
}

Received 14.03.2018, received in revised form 15.05.2018, accepted 22.05.2018

\begin{abstract}
This article is devoted to the role and place of the formal dogmatic approach in legal science in the modern world. The authors follow historical transnational discourse of the emergence of the formal dogmatic approach to the law, its methodological orientation and conditionality. The main attention is focused on the concept and essence of legal dogma, its scientific interpretation, its connection with legal technology. A comparative analysis of this approach and other legal research approaches has been made. The article determines theoretical and practical significance of the formal dogmatic approach in modern legal science and practice.
\end{abstract}

Keywords: formal dogmatic approach, legal science, method, dogma, legal technique.

DOI: 10.17516/1997-1370-0285.

Research area: law.

The formal dogmatic approach in jurisprudence is applied when studying normative legal material. This method consists in clarifying the meaning and significance of the rule of law, proceeding from its own content.

In legal science this method has various definitions: formal logical, formal legal and special legal. We call it formal dogmatic, because it is aimed at revealing the dogma of law.

S.S. Alexeev adhered to definitions of "formal dogmatic" (or techno-legal) in his scientific works. In his opinion, this approach reveals logical links regardless of various social, economic, political, cultural and other phenomena.

The formal dogmatic method of jurisprudence differs in different fields, though its functioning is limited. Despite the fact that the formal dogmatic method is limited to the sphere of application, it is of great importance for the development and realization of law as an integral phenomenon under the control of society and the state.

In this article we observe what constitutes a formal dogmatic approach in legal science in today's conditions; analyze the main categories in the framework of this approach, its principles, structure, sources, concept of law dogma, legal model, legal technique, doctrine of law, etc.

The formal dogmatic approach studies law as such, without considering it in economics, politics, ethics and other social sciences. The studied subject of the formal dogmatic approach

(C) Siberian Federal University. All rights reserved

* Corresponding author E-mail address: petrov av2012@mail.ru; lotos495@mail.ru 
in the legal science is law in its pure form, its conceptual apparatus, structure, models, legal technique (Babaev, 2003).

To question the formal dogmatic approach it is necessary to find out what is meant by "dogma".

"Dogma" in the legal sciences is understood as the attitude of people facing law, their attitude to life situations, on the basis of which legal cases are examined.

A great role belongs to Roman law and the process of its reception in the development of the formal dogmatic approach. Also, the dogma of law has been widely developed in the jurisprudence of the modern and contemporary history.

In the process of developing the formal dogmatic approach representatives of the historical school of law (Hugo, Puchta, Savigny) emphasized, on the one hand, the systemic nature of law, and, on the other, its effectiveness (Ivannikov, 2012).

One of the founders of the historical school of law G. Hugo considered legal dogmatics as one of the three components of jurisprudence along with philosophy and the history of law. Legal dogmatics is a combination of doctrine and dogmas of law. Hugo interpreted a legal dogma as "legal craft", for which it is sufficient to have knowledge about the sources of law.

According to G.F. Pukhta, legal methodology is an open system, capable of development in various conditions. K.F. von Savigny analyzed the systemic side of law, taking into account the specifics of its nature and history.

Representatives of the school of "analytical jurisprudence" (D. Austin, Sh. Amos, G. Hart, G. Kelsen, etc.) contributed to the process of developing the formal dogmatic approach (Nersesiants, 2004). For example, G. Kelzen while explaining his concept pointed out that pure tenet is a theory of positive law in general, rather than specific law and order. He argued that the doctrine of law is called pure, because it examines only law and frees it from everything that is not normative material. "Pure doctrine" seeks to relieve the institution from elements alien to it (Nersesiants, 2012).

On the whole, the positivist concepts of the formal dogmatic approach have had a significant impact on the complex development and improvement of law in accordance with its basic provisions on sources, system, structure, ways of interpretation, unification and systematization, forms of lawmaking and law enforcement.

Meanwhile, adherents of the natural legal views interpret the formal dogmatic method differently. According to S.S. Alekseev, "dogma of law" is a specific subject of legal knowledge - legal norms, precedents and customs are used as a basis for solving legal cases. Legal norms that operate in a society in a particular period of time are strictly defined reality and they must be applied in a primordial form, regardless of the attitude of society towards them (Alekseev, 2010).

Regarding the formal dogmatic approach as one of the directions of the legal science, one can single out dogmatics, technology, philosophy and sociology of law as its independent elements. Thus, in the framework of this approach, legal dogmatics is a relatively independent element of the general theory of law.

In Russia, the formal dogmatic approach began to be studied within the framework of the philosophy of law. Russian scientists of the late $19^{\text {th }}$ century (P.I. Novgorodtsev, S.N. Muromtsev) first of all paid attention to clarifying the essence of law as a social phenomenon and regulator of social relations. Law, as P.I. Novgorodtsev asserted, must be understood not only as a fact of social life, but also as a principle of personality. S.N. Muromtsev noted that dogma while being the basis is part of some art intended to study any law in force for its subsequent application in practice. The formal dogmatic approach does not seek to 
penetrate into the essence of phenomena. It only describes, classifies, generalizes the definitions of various legal facts on the basis of the system of law, in order to create the rules necessary to guide judicial practice.

At present, the formal dogmatic approach is the basis of legal technology, which is identified with dogma as a whole. It is studied as a structural part of the general theory of law, together with sociology and philosophy. In a narrow sense, legal technology is a collection of tools, techniques, methods of one of any sphere of normative activity: lawmaking, law enforcement, contractual sphere, etc. (Volkova, Malysheva, 2006).

For the formal dogmatic approach in legal science the following features are characteristic:

- conditional nature of legal models;

- correlation to formal logic;

- consistency of meaning and content;

- practical verification of scientific statements;

- applied character;

- integrity of meaning and content;

- multilateral character;

- systemic and interrelated categories, etc.

The formal dogmatic approach is used because the state legal phenomena are characterized by a two-sided structure. On the one hand, each of them has its own internal structure. On the other hand, each object acts as a part of united structure in which the state is an element of the political system of society; law is an element of norms and regulation; and the industry is an element of the legal system.

A special place is given to the functional characteristic of the structure elements, the definition and interrelation of their functions. Thus, in analyzing the apparatus of the state and the system of law, one can determine hierarchical relations (subordination or superiority), various kinds of functional ties (coordination, interaction) between state bodies and the elements of the law system. Thus, the formal dogmatic approach is aimed at identifying legal principles that characterize the system of law, its institutions and branches. In the process of creating a system of regulatory legal acts, they may be subject to adjustments. There is a correlation of principles in accordance with the will of the legislator, which does not always coincide with the interests of society. Using this approach, it is imperative to identify the links of the elements that give the system integrity and unity. In particular, in the process of analyzing the state and the legal system, a consistent interaction (superiority, subordination, coordination, etc.) is established. The formal dogmatic approach ensures the integrity of the phenomenon under study, its elements, a certain order and connections between the components.

Proponents of the formal dogmatic approach, based on positivist epistemology, limited themselves to analyzing the normative material and investigating legal models. In this regard, the legal dogmatics studied in this approach is a means of formalizing law by building legal models. The legal model in its general form is a method of study aimed at transforming law into a hierarchical system of precise terms and concepts. It is a kind of construction of rights, duties and responsibilities, in which normative material is implemented. Along with this, the legal model can be used only if the principles underlying the existing legal norms are mastered and when there is periodic verification of lafal norms' generalizations. The legal model as a means of formalizing legal norms and fixing normative material is a part of legal dogmatics, since it explains the essence of dogma and structures legal norms.

The legal model finds its expression in the sources of law. Sources of law in the general sense are documentary ways of introducing and 
fixing the norms of law officially sanctioned by the state and having a universally binding value. The source of law is given in the normative legal text, which also offers information about the legal norm. Meanwhile, the official text, which does not contain a norm, but merely lists the rights and obligations of specific subjects, is not a source of law. This is a law enforcement document and it is considered to stem directly from the very source of law (for example, a judgment). But a nonnormative document can be a source if it does not have a specific legal norm, but establishes the rights and obligations of legal entities. Such cases took place in Ancient Rome and the Byzantine Empire, at the initial stages of the development of the Roman legal system. These are court sentences for specific cases, and private contracts entailing the same consequences for entities that are not based on existing legal norms (Chetvernin, 2003).

In addition to this, natural legal concepts do not change the main thing. For instance, against the absence of a single origin in the methodological and ideological positions, in the theory of state and law, there are fundamentally opposing theories natural legal and positivistic. This is most clearly manifested in the interpretation of the concept of law. The theory of natural law, inalienable human rights, the existence of a legislative base, etc., are proclaimed, but at the same time, law is still defined in the spirit of legal normativism, which regards it only as an objective logical form (Bainiiazov, 2001).

Famous Dutch scientist of the $17^{\text {th }}$ century G. Grotius, covering the relationship of natural legal and legal positivism concepts, argued that natural law is revealed through the category of justice. Its source is not the expression of the will of the subject, but the man's conscious desire to communicate with others (Grotius, 1994). The source of the positive law is the will of a man or God. The most positive law is divided into public (state, international) and divine law (the Bible). Both state and international law are based on natural law (Nersesiants, 2004). In the teachings of Grotius, it is natural law and its reasonableness and justice that determine the normative nature of positive law and affirm the unity of the subject of jurisprudence as legal science.

For a long time the doctrine of law has been one of the main ones, and in some cases, in various legal systems of the world - the main source of law. Today it is very significant in the entire law enforcement process, and in some legal systems it is officially considered a source of law. The specific features of the doctrine of law are that it is not the result of the daily activities of state bodies or civil society, but is expressed in the principles, judgments, models, contracts, legal practices formulated by leading legal scientists. Displaying legal force, these elements acquire the factor of the social regulator of social relations. In ancient Rome the right of making judgment and forming opinions belonged to the best legal scholars, who later formed Roman law, called as a doctrine (Dozhdev, 2003).

Considering the main source of law for the world's leading legal systems, one sees that the doctrine of law attributes them to the appropriate legal families. These are traditional (system of customary law) and Roman-German legal families. Under dogma they understand the direction of the doctrine of law of a particular law school; basic provisions on the positive law and its operation at the moment. At the same time, doctrine is considered to be the main element of the dogma of law.

The leading role of the dogma of law and its constituent elements (legal norms, rights and obligations of subjects, legal relations, sources of law, normative material, doctrine of law) gives the formal dogmatic approach a basic role in the application of general scientific methods. The formal dogmatic method is associated 
with the application of the rules of logic and language, since the existence of law is inherent in the normative material: legal acts, treaties, orders, judgments, etc., and their interpretation in connection with specific events. For example, here we distinguish between the theoretical application of the formal dogmatic approach (the doctrine of law) and practical application (official interpretation).

With the help of the formal dogmatic approach, research is being carried out to develop scientific definitions, distinguish directions of legal activity, etc. For legal science the distinction between the language and the metalanguage of law matters. The legal language is a language that is reflected in normative legal acts and legal practice. The metalanguage of law is a language of jurisprudence and its basic disciplines, for example, the theory of state and law, constitutional law, etc.

One of the problems of modern usage of the formal dogmatic approach in the legal system is associated with the increasing mobility (variability) of law dogma. In this regard, it is necessary to supplement the formal dogmatic approach with elements of the hermeneutical approach, for which dissemination is typical for understanding the subject and awareness. This will help to overcome the impermanence of the dogma of law and come to a decision.
In conclusion, we shall mention that jurisprudence can achieve its goals and be used for its own purpose when it puts forward the original provisions within the legal system, i.e. doctrine. The doctrine can be the subject of mastering jurisprudence, studying the patterns of the existence of law as the language, in which the communication of subjects takes place (for maintaining public order). Meanwhile, the predominance of the formal dogmatic approach can theoretically lead to essential limitations in the process of cognition, since legal science has legal positivism in its basis.

The dogma of law is as different as natural law involved. According to the formal dogmatic approach, law is formalized, structured and then systematized. At the same time, the dogma of law is the product of an inanimate social reality, consistently generating legal practice. S.S. Alekseev is right in his statement, calling the dogma a concrete legal reality, independent of the subjects' opinion of the legal relationship. Law is reified directly in the legal relationship, the activities of its participants, the realization of their rights and obligations, when the whole meaning of existence and the value of the dogma of law manifest themselves straightforwardly.

\section{References}

Alekseev, S.S. (2010). Sobranie sochinenii. Tom 7 [Collection of works. Volume 7]. Moscow, "Statute", 495 p.

Babaev, V.K. (2003). Teoriia gosudarstva i prava [Theory of State and Law]. Moscow, "Iurist", $592 \mathrm{p}$.

Bainiiazov, R.S. (2001). Filosofiia pravosoznaniia: postanovka problemy [Philosophy of legal awareness: statement of the problem], In Jurisprudence. 5, 12-23.

Chetvernin, V.A. (2003). Vvedenie v kurs obshchei teorii prava i gosudarstva [Introduction to the course of the general theory of law and state]. Moscow, Institute of State and Law of the Russian Academy of Sciences, $204 \mathrm{p}$.

Dozhdev, D.V. (2003). Rimskoe pravo [Roman Law]. Moscow, Infra-M, Norma, 784 p.

Grotius, G. (1994). O prave voiny i mira [On the law of war and peace]. Moscow, Ladomir, 868 p. 
Ivannikov, I.A. (2012). Teoriia gosudarstva i prava [Theory of state and law]. Moscow, RIOR, Infra-M, Academic Center, $352 \mathrm{p}$.

Nersesiants, V.S. (2004). Istoriia politicheskikh i pravovykh uchenii [History of political and legal doctrines]. Moscow, Norma, 944 p.

Nersesiants, V.S. (2012). Obschaia teoriia prava i gosudarstva [General theory of law and state]. Moscow, Norma, INFRA-M, $560 \mathrm{p}$.

Volkova, S.V., Malysheva, N.I. (2006). Mezhvuzovskaia konferentsiia o problemakh iuridicheskoi tekhniki [Interuniversity Conference on the Problems of Legal Technics], In Jurisprudence. 2, 182-195.

\title{
Формально-догматический подход \\ в юридической науке в условиях современности
}

\author{
А.В. Петров, А.В. Зырянов \\ Южно-Уральский государственный университет \\ Россия, 454080, Челябинск, пр. Ленина, 76
}

Настоящая статья посвящена вопросу роли и места формально-догматического подхода в юридической науке в условиях современности. Осуществлен исторический транснациональный дискурс становления формально-догматического подхода к праву, его методологической направленности и обусловленности. Акцентировано внимание на понятии и сущңности правовой догмы, ее научной интерпретации, связи с юридической техникой. Произведен сравнительный анализ указанного подхода с иными подходами юридических исследований. Определена теоретическая и практическая значимость формально-догматического подхода в современной юридической науке и практике.

Ключевые слова: формально-догматический подход, юридическая наука, метод, догма, юридическая техника.

Научная специальность: 12.00.00 - юридические науки. 